\title{
Positive temperature effects on the initiation and intensity of cannibalistic behaviour of larval pike, Esox lucius L. Is cannibalism reflected in otolith fluctuating asymmetry?
}

\author{
Martyna Greszkiewicz $\mathbb{D}$ - Dariusz P. Fey
}

Received: 27 November 2019/Revised: 6 April 2020/ Accepted: 9 June 2020/Published online: 16 June 2020

(C) The Author(s) 2020

\begin{abstract}
Cannibalism can be a significant factor limiting the survival of pike, Esox lucius, early life stages in both natural and aquaculture conditions. In the present research, type I cannibalism was studied in pike larvae (size range: 9-32.5 mm standard length, SL) in controlled conditions for 45 days post-hatching (dph). For this purpose, the occurrence of cannibalistic pairs, i.e. prey caught by a cannibal inside the cannibal's mouth, was monitored for 15 min periods by two observers six times daily. Cannibalism was not observed in fish that still had yolk-sacs, but it did occur as soon as the yolk-sac was absorbed on $5 \mathrm{dph}$ at a body size of $13 \mathrm{~mm}$ at $22{ }^{\circ} \mathrm{C}$ and $10 \mathrm{dph}$ at a body size of $13.4 \mathrm{~mm}$ at $15{ }^{\circ} \mathrm{C}$. The ratio of prey to predator size was on average $87 \%$, but the smallest observed size difference was only $1.3 \%$. The intensity of cannibalistic attacks depended on water temperature with more intense cannibalism at $22{ }^{\circ} \mathrm{C}$ than at $15{ }^{\circ} \mathrm{C}$, and no cannibalism at $10{ }^{\circ} \mathrm{C}$. Fluctuating asymmetry (FA) in all three sagittal otolith size parameters (area, width, and length) was higher in prey than in cannibals, the differences were not statistically significant.
\end{abstract}

Handling editor: Pauliina Louhi

M. Greszkiewicz $(\bowtie) \cdot$ D. P. Fey

Department of Fisheries Oceanography and Marine

Ecology, National Marine Fisheries Research Institute, ul.

Kołłątaja 1, 81-332 Gdynia, Poland

e-mail: mgreszkiewicz@mir.gdynia.pl
Keywords Cannibalistic behaviour - Fish larvae · Mortality $\cdot$ Bilateral instability

\section{Introduction}

The phenomenon of cannibalism is observed in many animal groups, inter alia, in protozoa, rotifers, snails, copepods, mites, insects, spiders, fish, amphibians, birds, and mammals (Fox, 1975). Increasing evidence indicates that cannibalism is not only common but that it is important to the ecology of many species. Fox (1975) concluded that cannibalism is a natural behaviour in 147 species, while Polis (1981) cites reports on approximately 1300 species. Smith \& Reay (1991) define cannibalism more precisely as an act of killing and consuming wholly or in large part an individual belonging to the same species regardless of developmental stage. Similarly, Garcia \& ZaniboniFilho (2006) defines cannibalism as a special type of predation that depends on killing individuals of the same species for partial or total consumption.

Among fish, the phenomenon of cannibalism has been identified unequivocally in the literature in 36 of 410 teleost fish families (Nelson, 1984). It is likely, however, that cannibalism in fish is more widespread than a literature review can suggest (Dominey \& Blumer, 1984) since the phenomenon has been described in the literature mainly in species that are 
of interest to humans as resources, are used as models in behavioural studies, or are popular species in fishkeeping (Smith \& Reay, 1991). Pereira et al. (2017), who reviewed more than 1000 articles on fish cannibalism, conclude that this phenomenon among marine fishes occurs most frequently among Gadidae (106 records, Atlantic cod, Gadus morhua dominant), Gobiidae (54 records, common goby, Pomatoschistus microps, dominant), and Merlucciidae (29 records, genus Merluccius dominant), while among freshwater fishes it occurs among Percidae (140 records, European perch, Perca fluviatilis, and yellow perch, $P$. flavescens, dominant), Salmonidae (75 records, Arctic char, Salvelinus alpinus, dominant), and Esocidae (54 records, Northern pike, Esox lucius, dominant).

Although cannibalism occurs in both early developmental stages and adult fish, most instances of cannibalistic behaviour refer to the consumption of larvae or juvenile individuals (Pereira et al., 2017). This is true for the pike analysed in the current study in which cannibalism is particularly widespread in the first year of life (Craig, 1996). Feeding habits in young pike change as they grow and three feeding stages occur during development (Hunt \& Carbine, 1951). This feeding sequence progresses with pike growth from lower crustaceans to insects, and then to fish. It is supplemented, even at an early developmental stage (15-20 mm), by attacks on larval fish, including cannibalistic attacks (Hunt \& Carbine, 1951; Morrow et al., 1997; Mamcarz et al., 1998; Žiliukienė \& Žiliukas, 2006).

Cannibalism is divided into seven classes according to the developmental stage of the prey, the genetic relationship between the cannibal and its prey, and the age relationship between them (Smith \& Reay, 1991). According to the classification by Smith \& Reay (1991), pike belongs to the class of "sibling intracohort cannibalism of post-hatching stages." This class is characterized by sibling cannibalism or individuals belonging to the same age class, which is typical of piscivorous species in larval and juvenile early life stages (Naumowicz et al., 2017). Bearing in mind the methodology used in the present research and size range of analysed fish, type I cannibalism is considered. This occurs when the size of the prey is large relative to that of the predator, it can be ingested tail first (or less frequently head first) and consumed (Cuff, 1980); this is in contrast to type II cannibalism, which is characterized by the cannibal immediately and completely ingesting the prey (Baras \& Jobling, 2002).

The ability to eat siblings in early life stages before offspring disperse, which occurs in pike, is facilitated by the pike's large gape and well-developed dentition shortly after hatching (Giles et al., 1986). Cannibalistic larvae usually have augmented dentition, large gape size, and increased jaw musculature (Folkvord, 1997). In both adult and early life stages of pike, the long build of the body and its articulated jaw and backward-facing hinged teeth prevent prey from escaping, and the combination of the propellant force of the anal, caudal, and dorsal fins helps to obtain high acceleration when attacking prey (Craig, 1996; Skov $\&$ Nilsson, 2018). Additionally, the underslung pairs of pectoral and pelvic fins enable precise manoeuvring to sight prey stereoscopically down paired snout grooves (Craig, 1996).

In the natural environment, cannibalism is a key mechanism for regulating pike abundance that has significant implications for pike year class recruitment (Craig \& Kipling, 1983) and also for the structure of given populations (Skov \& Nilsson, 2018). It is especially important for over-exploited populations, which can be found not only in freshwater systems but also in many coastal areas of the Baltic Sea (Nilsson et al., 2014; Larsson et al., 2015; Skov \& Nilsson, 2018). Although the main reasons for population declines are over-exploration and the disappearance of suitable spawning grounds and low recruitment (Skov \& Nilsson, 2018), other factors related to human activities in coastal areas (e.g. wind farms and underwater cables) should also be considered (Fey et al., 2019). When there is a lack of recruitment from natural spawning, local populations are often supported by stocking with pike larvae or fry obtained from recirculating aquaculture systems (RAS), which have been found to be very efficient in producing pike stocking material (Szczepkowski et al., 2012). Unfortunately, cannibalism among pike early life stages plays a significant role not only in natural but also in aquaculture conditions because it can cause total losses that exceed $90 \%$ of total mortality (Szczepkowski, 2009). The significance and potential consequences of the occurrence of cannibalism during larval and juvenile stages mean it is extraordinarily important to acquire an understanding of this phenomenon.

There are several methods for determining the condition and fitness of fish specimens, including 
methods that evaluate Fulton's condition factor (Jin et al., 2015), morphology and histology (Theilacker, 1986), lipid and protein composition (Håkanson, 1989; McCormick \& Molony, 1993), RNA to DNA ratios (Clemmesen, 1988; Folkvord et al., 1996; Peck et al., 2015), and otolith microstructure (Campana \& Jones, 1992). Alternatively, fitness is reflected in developmental instability (Zakharov, 1992). Developmental instability can then be reflected in fluctuating asymmetry (Palmer, 1994), which is defined as a random deviation in a perfect bilateral system (Palmer, 1994). Assuming environmental stress causes developmental instabilities, high fluctuating asymmetry can indicate the lower condition of larvae that experienced unfavourable environments. The link between fish condition and fluctuating asymmetry has been studied in both adult and larval fish, and a number of measurements have been analysed, including otolith size and shape (Escós et al.,1995; Somarakis et al., 1997a, b; Fey et al., 2020). However, the results obtained in different studies are inconsistent. Presumably, whether fish larvae belong to cannibal or prey groups within a cannibalistic population depends on differences in both growth rates and fish condition. The question posed in the present study is whether there are also differences in developmental instability that are reflected in fluctuating asymmetry in otolith size between groups of cannibals and prey. Although otolith growth and daily otolith increment deposition have recently been analysed for larval and early juvenile northern pike (Fey et al., 2018), no information on otolith asymmetry has been published to date.

The aim of the present study was to determine for larval pike (9-32.5 $\mathrm{mm} \mathrm{SL}$ ) held under controlled conditions if the water temperature $\left(10,15,22{ }^{\circ} \mathrm{C}\right)$ had an effect on the age and size of predators during the first cannibalistic attacks, the intensity of the cannibalism phenomenon, and the proportion of prey to predator body size. The methodology used chosen to analyse type I cannibalism (the cannibal ingests its prey by the tail or head first). Additionally, whether belonging to predator or prey groups was related to the presence of higher or lower organism bilateral instability was also verified by analysing otolith size fluctuating asymmetry.

\section{Materials and methods}

Experimental conditions

The experiments were performed in nine freshwater tanks with volumes of $55 \mathrm{~L}$ each combined into three RAS providing three temperatures (mean $\pm \mathrm{SD}$ ): $10 \pm 0.6{ }^{\circ} \mathrm{C}, 15 \pm 0.4{ }^{\circ} \mathrm{C}, 22 \pm 0.5^{\circ} \mathrm{C}$, with three replicates of each temperature (3 temperatures $\times 3$ replicates). Each of the systems was equipped with UV sterilization and a filtering-deposit container with a volume of $70 \mathrm{~L}$ providing both mechanical and biological filtration. The volume of biological filtration was $20 \mathrm{~L}$. In each of the tanks a green plastic net (mesh size $0.5 \mathrm{~cm}$ ) formed into a roller $(20 \mathrm{~cm}$ in length $\times 8 \mathrm{~cm}$ in diameter) was used as a substitute for bottom substrate. The colour of the tank bottom was grey, and the glass walls were not covered. The tanks were located in a completely dark room in which light conditions $(\sim 100$ Lux on the water surface, $12 \mathrm{~h}$ light/12 h dark, with light on from 8.00 to 20.00) were regulated automatically. Water temperature was measured three times daily with electronic temperature readers. The oxygen level during the experiment was measured daily and was $7.8 \pm 0.9 \mathrm{mg} \mathrm{l}^{-1}$ in all tanks (mean $\pm \mathrm{SD}$ ) throughout the experiment.

The rationale for choosing the particular temperatures was to cover the wide range of temperatures that larvae encounter in natural conditions depending on the type of water body and depth. Temperatures typically range between 10 and $15{ }^{\circ} \mathrm{C}$, but they can exceed $22{ }^{\circ} \mathrm{C}$ in shallow flooded fields where the water depth is only several centimetres. Two temperatures $\left(15{ }^{\circ} \mathrm{C}\right.$ and $\left.22{ }^{\circ} \mathrm{C}\right)$ correspond to conditions that can occur in aquaculture systems.

The total time of experiment was 45 days, but this differed depending on the temperature: 17 days at $22{ }^{\circ} \mathrm{C}$ (no fish left beyond this point), 37 days at $15^{\circ} \mathrm{C}$ (no fish left beyond this point), and 34 days at $10^{\circ} \mathrm{C}$ (no cannibalism occurred). On day 34, the fish from the $10{ }^{\circ} \mathrm{C}$ treatment were transferred to the $15^{\circ} \mathrm{C}$ treatment for 11 days (group $10-15^{\circ} \mathrm{C}$ ). The rationale behind the transfer from 10 to $15{ }^{\circ} \mathrm{C}$ was to test if cannibalism was triggered at the higher temperature and after how many days (see results for the information about no cannibalism at $10{ }^{\circ} \mathrm{C}$ ). The scheme of the experimental setup is presented in Fig. 1. 


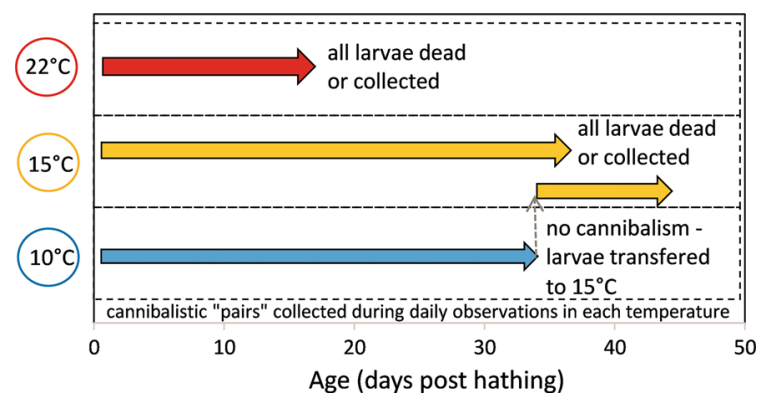

Fig. 1 Scheme of the experimental setup. The transfer of larvae from 10 to $15{ }^{\circ} \mathrm{C}$ on day 34 was a consequence of no cannibalistic attacks at $10{ }^{\circ} \mathrm{C}$

\section{Fish larvae rearing}

Eyed-egg pike embryo were transported to the laboratory from a commercial hatchery, and 3000 eggs obtained from one female were placed in separate bags for transportation. The number of eggs was estimated by the volumetric method using a glass cylinder with a calibration scale (Szczerbowski, 2008). Mass hatching occurred during the first hour of transportation, and the hatched larvae were placed in tanks (one bag in one tank). The unhatched eggs left in the bags were counted to estimate the number of larvae in each tank. Hatching success was within a range of $92-95 \%$ in all of the transportation bags. The temperature was set to $10{ }^{\circ} \mathrm{C}$ in each tank at the beginning of the experiment. Thereafter, the temperature was increased to $15^{\circ} \mathrm{C}$ within $24 \mathrm{~h}$ in one of the systems and to $22{ }^{\circ} \mathrm{C}$ within $48 \mathrm{~h}$ in the other one, and it was constant thereafter. Following yolk-sac absorption, feeding was conducted ad libitum every $1.5 \mathrm{~h}$ during periods with light with specialist fodder, as follows: ArtEX 2 (0.15 mm) (Aller Aqua) for the first 4 days after yolk-sac absorption; Perla Larva Proactive $4.0(0.3-0.5 \mathrm{~mm})$ (Skretting AS) from day 3 after yolk-sac absorption. Dead fish, unconsumed fodder, and excrement were cleaned from the tank bottoms every morning. The number of dead fish in each tank was counted to calculate the current density of larvae in each tank as well as the cannibalism intensity index (see data analysis section).

\section{Cannibalism analysis}

During each feeding (i.e. six times daily, every $1.5 \mathrm{~h}$ during the light period), the occurrence of cannibalistic pairs, i.e. prey caught by a cannibal inside its mouth (Fig. 2), was monitored in all tanks simultaneously for 15 min periods by two observers. Because only cases when prey was inside mouth of the cannibal were counted as cannibalistic attacks, this approach can be considered to be the analysis of successful cannibalism. Each pair was collected, and after placing it in $800 \mathrm{mg} \mathrm{l}^{-1}$ MS-222 anaesthetic fluid (ACROS Organics ${ }^{\mathrm{TM}}$, Belgium), it was transferred into an individual vial (one pair per vial) of $96 \%$ alcohol to preserve the material for otolith asymmetry analysis. Although the approach described did not provide information on the absolute number of cannibalistic attacks, it permitted calculating the relative type I cannibalism intensity index that is comparable among the three temperatures. A total of 71 cannibalistic pairs was collected.

The alcohol in each vial was changed after two weeks since it has been demonstrated that alcohol storage can damage otoliths and affect the results of otolith size measurements (Fey, 2018), which would
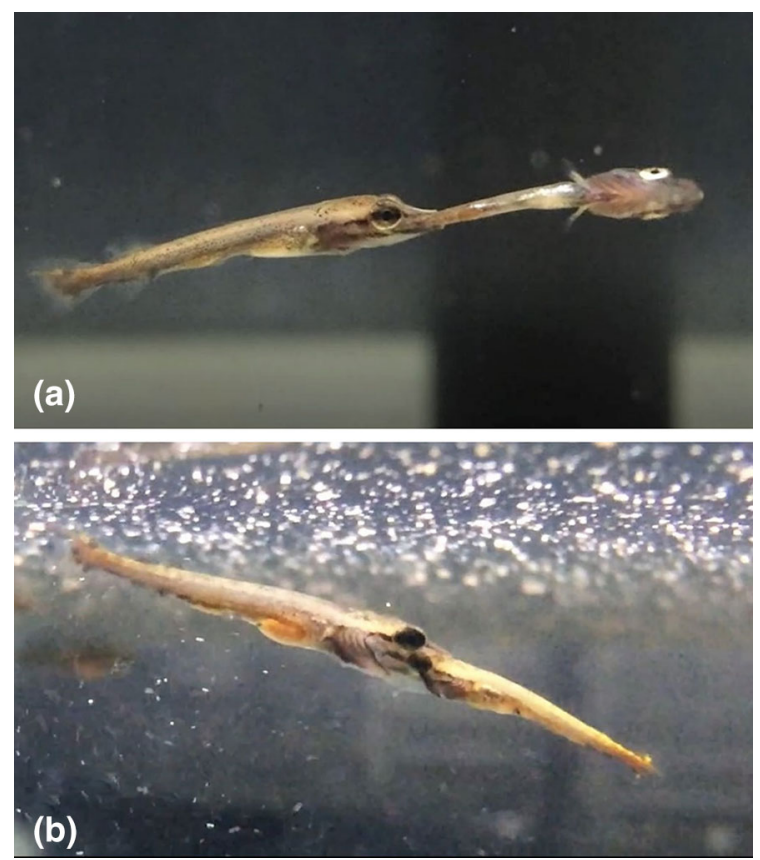

Fig. 2 Picture of a cannibalistic pair of pike (Esox lucius) representing type I cannibalism (without immediate ingestion). The cannibal holds the prey, which is not much smaller, by the tail (a). Once the difference in size between cannibals and prey increased, the attacks from the side and head were also observed (b). Only instances in which the prey's body was inside the cannibal's mouth were considered to be cannibalistic attacks in this study. All "connected" pairs were collected and analysed 
influence the results of otolith size asymmetry analysis performed for the current study. Cannibal and prey body sizes (standard length, SL) were measured with an electronic calliper to the nearest $0.1 \mathrm{~mm}$ a few weeks after collection. For the purpose of background description (i.e. larvae size, both prey and cannibals, in a given tank in a given temperature), 10 larvae were collected every three days and placed first in the anaesthetic fluid and then in alcohol. The SL of these larvae were measured to the nearest $0.1 \mathrm{~mm}$ within a few weeks. The size of the preserved specimens was corrected for alcohol shrinkage, and unpreserved size was calculated with a correction factor $(+0.7 \mathrm{~mm})$ (Greszkiewicz \& Fey, 2018). The size range of the larvae collected from cannibalistic pairs was between 11.8 and $32.5 \mathrm{~mm}$ SL.

Otolith fluctuating asymmetry analysis

Otoliths (left and right sagitta) were extracted from each larva and placed in DePeX mounting medium (Electron Microscopy Sciences, Fort Washington, PA) on microscope slides. The size of the otoliths was measured with an image analysis system (Image-Pro Premier, Media Cybernetics, Inc., Rockville, MD) under an Eclipse 80i transmitted light microscope (Nikon Corp., Tokyo, Japan).

The fluctuating asymmetry of otoliths (left otolith - L , and right otolith-R) was analysed according to methods described by Fey \& Hare (2008). First, it was verified that the (L-R) was not different from zero (one-sample $t$ test to 0 ) and that the distribution of differences was normally distributed (Shapiro-Wilk $\mathrm{W}$-test) and free from antisymmetric (bimodality or platykurtosis) and directional symmetry (skew). Linear regression analysis was then employed to test if the absolute difference between the left and right otolith size ( $(\mathrm{L}-\mathrm{R} \mid)$ depended on trait size (i.e. otolith size). The largest measurement (left or right otolith) was used as the trait size since Sullivan et al. (1993) demonstrated that using the mean value as trait size can introduce a spurious correlation and should be avoided. The analysis was performed for cannibals and prey separately. Since the $|\mathrm{L}-\mathrm{R}|$ was not dependent on trait size, the mean $|\mathrm{L}-\mathrm{R}|$ was used as the fluctuating asymmetry index (FA). The comparison was based on the $n=71$ cannibals and $n=71$ prey sample size.
Data analysis

The time (dph) of the first cannibalistic attack and the size of the cannibals in the attacks were compared among the temperatures. How cannibalism intensity changed over time (i.e. with changing fish density in tanks and fish size) and what the effect of temperature was on the phenomenon were analysed with the cannibalism intensity index $\mathrm{CI}(\%)$ that was calculated for each sampling day:

$\mathrm{CI}=N_{\text {canib }} / N_{\text {all }} \cdot 100$

where $N_{\text {canib }}$ is number of cannibalistic pairs collected on a given day in a given tank and $N_{\text {all }}$ is number of all larvae in the tank.

The number of larvae in a given tank on a given day was estimated by subtracting the number of dead fish found during morning cleaning on that day and during previous days from the number of fish in that tank at the beginning of the experiment (i.e. number of eggs in the transportation bag minus unhatched eggs).

The CI was plotted against SL (mm) and larvae density $\left(n \cdot \mathrm{L}^{-1}\right)$ separately for the three temperature groups. The growth rate of the cannibals and the prey was compared with slope comparison (ANCOVA) of linear functions fitted to SL at age data. The differences in the FA between cannibals and prey were evaluated using the $t$ test. All those analyses were conducted after data were pooled among the three subsample tanks for each temperature to obtain a sufficient number of observations for this calculation. Still, it was beneficial to have subsamples from three tanks as the CI index calculations were performed for the specific conditions (density and larval size) the larvae encountered in each of the tanks. Statistica, version 12.0 (TIBCO Software, Inc., Palo Alto, CA) software was used for data analysis. Differences were considered statistically significant at $P<0.05$ $(\alpha=0.05)$.

\section{Results}

First cannibalistic attack—cannibal size and age

In total, 71 cannibal-prey pairs representing larva size ranges from 11.8 to $32.5 \mathrm{~mm} \mathrm{SL}$ were collected during the experiment. Thus, successful attacks were evaluated without considering unsuccessful attacks or bites 
only. The first successful cannibalistic attack was observed $5 \mathrm{dph}$ at $22{ }^{\circ} \mathrm{C}, 10 \mathrm{dph}$ at $15{ }^{\circ} \mathrm{C}$, and no attacks were observed at $10{ }^{\circ} \mathrm{C}$ (Fig. 3). Cannibal size at the first attack was $13.0 \mathrm{~mm}$ at $22{ }^{\circ} \mathrm{C}$ (Fig. 3a) and $13.4 \mathrm{~mm}$ at $15^{\circ} \mathrm{C}$ (Fig. 3b). When the fish were transferred from 10 to $15^{\circ} \mathrm{C}(34 \mathrm{dph}$, size range 14.4-19.4 mm), the cannibalistic attacks started after 5 days at a cannibal size of $19.8 \mathrm{~mm}$ (Fig. 3c). Fish from the full-size range present in the tanks at a given time participated in the cannibalistic phenomenon with cannibals representing approximately the upper half of the size range of all the larvae in the tanks and the prey representing the lower half of the size range (Fig. 3).

The first attacks at 15 and $22{ }^{\circ} \mathrm{C}$ were from the tail only (Fig. 2a). At a cannibal size of approximately $17 \mathrm{~mm}$, attacks from the side and head (Fig. 2b) were also noted and they represented $10 \%$ (side) and $14 \%$
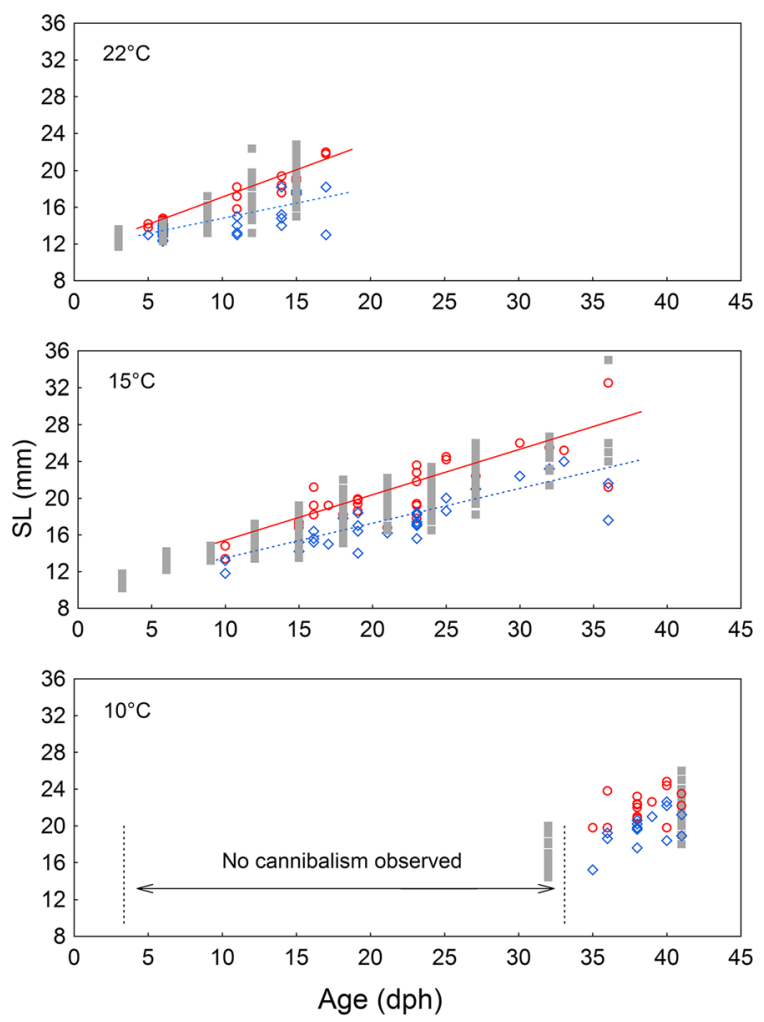

Fig. 3 Standard length (SL, mm) of larval pike, Esox lucius, cannibals (circle and solid line), prey (diamond and dashed line), and other specimens present in the tanks (filled square) on individual days after hatching at three different temperatures: $22{ }^{\circ} \mathrm{C}(\mathrm{A}), 15{ }^{\circ} \mathrm{C}(\mathrm{B}), 10{ }^{\circ} \mathrm{C}(\mathrm{C})$. Each point represents an individual fish. The data were pooled for three tanks at each temperature (head) of all the attacks among larvae from the 17-32 $\mathrm{mm}$ size range.

Prey to cannibal size ratio

The prey size to cannibal size proportion ranged, on average, from $95 \%$ for $13 \mathrm{~mm}$ fish to $80 \%$ for $27 \mathrm{~mm}$ fish, with a mean for all specimens of $87 \%$ (Fig. 4). The smallest differences in size between the prey and cannibals (approximately $0.2 \mathrm{~mm}$ ) occurred in the cannibal size range from 13.4 (difference $=1.5 \%$ ) to $18.4 \mathrm{~mm}$ (difference $=1.1 \%)$. There was no temperature effect on the analysed proportion (Fig. 4).

Growth rate of cannibals and prey

The growth rates of cannibals and prey was estimated from the slopes of regression lines fitted to SL at age data. The growth rate of larvae at $22{ }^{\circ} \mathrm{C}$ was $0.57 \mathrm{~mm} \cdot \mathrm{day}^{-1}$ for cannibals and $0.32 \mathrm{~mm} \cdot \mathrm{day}^{-1}$ for prey (Fig. 3a). At $15^{\circ} \mathrm{C}$, the growth rate of cannibals was 0.55 and of prey it was $0.43 \mathrm{~mm} \cdot$ day $^{-1}$ (Fig. 3b). The differences between the growth rates of cannibals and prey were statistically significant for both 15 and $22{ }^{\circ} \mathrm{C}$ (ANCOVA, slope: $P<0.05$ ). Since the slopes were different, no comparison was made for the elevations of the regression lines. In the $10-15{ }^{\circ} \mathrm{C}$ group, growth was not calculated because of the narrow size range of the larvae. However, the cannibals were clearly larger at age (i.e. at dph) than

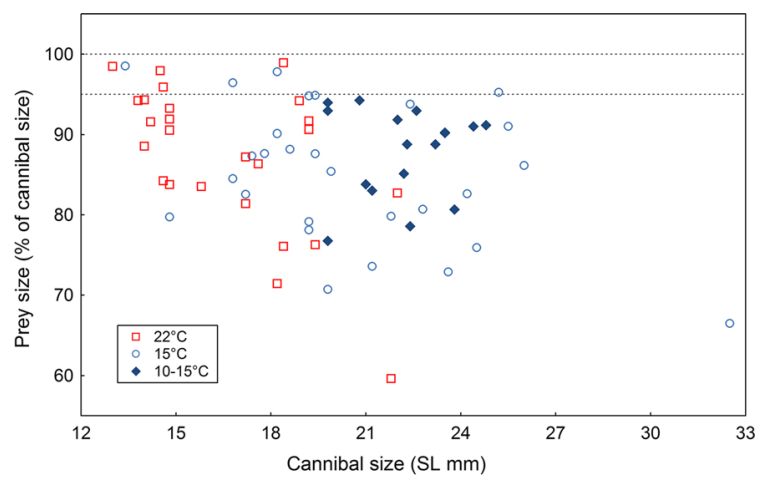

Fig. 4 Percentage values of the proportion of prey size to cannibal size of larval pike, Esox lucius, at three different temperatures: $22{ }^{\circ} \mathrm{C}$ (squares), $15^{\circ} \mathrm{C}$ (circles), $10-15^{\circ} \mathrm{C}$ (diamonds; fish transferred from 10 to $15{ }^{\circ} \mathrm{C}$ after 34 days of the experiment). The range of the highest similarities (range of $95-100 \%$ ) in sizes between cannibals and prey is marked with a dashed line 
the prey (Fig. 3c), and the difference was statistically significant ( $\mathrm{t}$ test, $P<0.01$ ). This difference indicated that the growth rate of cannibals was faster than that of the prey.

Temperature effect on cannibalism intensity

Cannibalism intensity increased with time at each temperature (Fig. 5), and it corresponded to decreasing larval density in the tanks (Fig. 5) and to increasing fish size (Fig. 3). To account for these two factors-density and fish size-the effect of temperature on CI was analysed by plotting CI against SL (Fig. 6) and against fish density in the tanks (Fig. 7). In both comparisons, cannibalism intensity was higher at $22{ }^{\circ} \mathrm{C}$ compared to the $15^{\circ} \mathrm{C}$ and $10-15{ }^{\circ} \mathrm{C}$ groups. Cannibalism intensity in the $15^{\circ} \mathrm{C}$ groups was the same as in the $10-15{ }^{\circ} \mathrm{C}$ group. These differences were statistically significant (ANCOVA for log-transformed data, intercept $P<0.05$ ).

Cannibalism and otolith fluctuating asymmetry

The FA of otolith size (area, length, and width of sagitta) was compared between prey $(n=71)$ and cannibals $(n=71)$ (Table 1, Fig. 8). Although the FA for all the otolith size variables was higher for prey compared to cannibals, the differences were not statistically significant (paired t test, $P>0.05$ ).

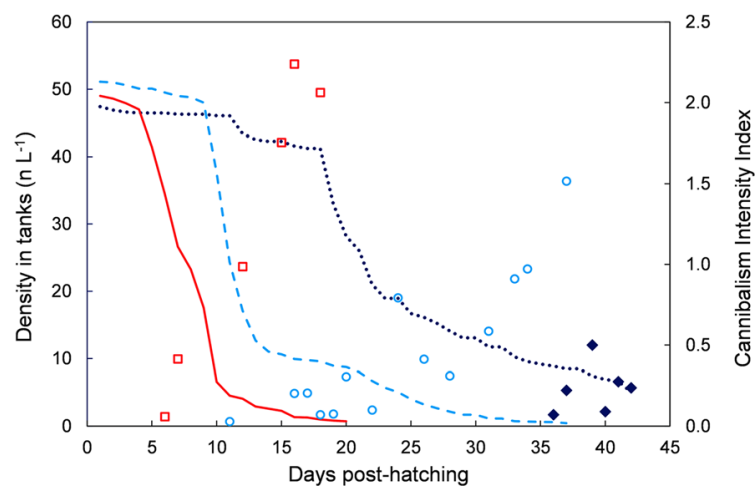

Fig. 5 Comparison of changes in the timing of cannibalism intensity (Cannibalism Intensity Index) and density of larvae in tanks for pike, Esox lucius, at three different temperatures: $22{ }^{\circ} \mathrm{C}$ (square and solid line), $15{ }^{\circ} \mathrm{C}$ (circle and dashed line), $10-15{ }^{\circ} \mathrm{C}$ (fish transferred from 10 to $15^{\circ} \mathrm{C}$ after 34 days of the experiment) (diamonds, dotted line)

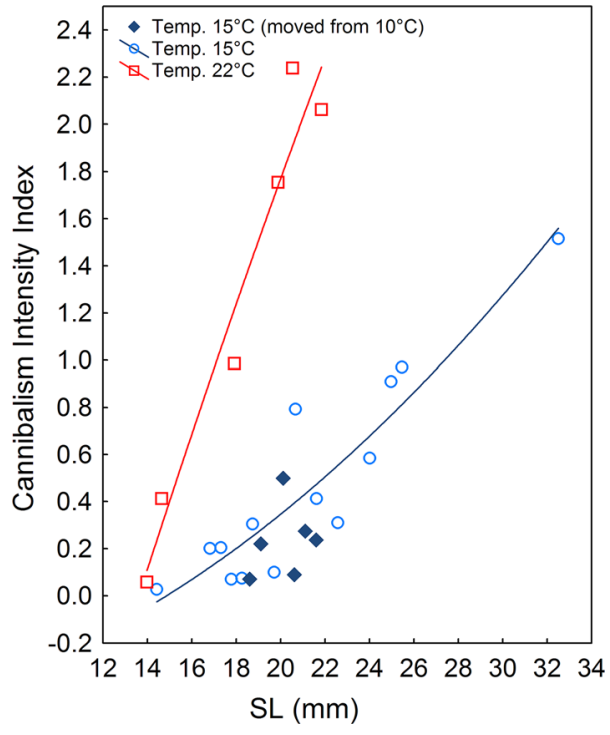

Fig. 6 Cannibalism intensity (Cannibalism Intensity Index) depending on individual standard length for larval pike, Esox lucius, at three different temperatures: $22{ }^{\circ} \mathrm{C}$ (square and solid line), $15{ }^{\circ} \mathrm{C}$ (circle and solid line), $10-15{ }^{\circ} \mathrm{C}$ (fish transferred from 10 to $15{ }^{\circ} \mathrm{C}$ after 34 days of the experiment) (diamonds, no line was fitted)

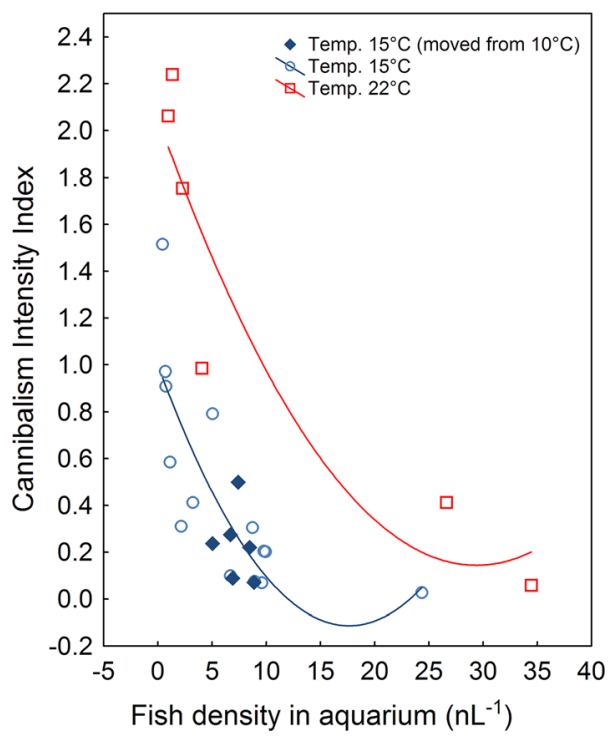

Fig. 7 Cannibalism intensity (Cannibalism Intensity Index) depending on fish density in tanks for larval pike, Esox lucius, at three different temperatures: $22^{\circ} \mathrm{C}$ (square and solid line), $15{ }^{\circ} \mathrm{C}$ (circle and solid line), $10-15{ }^{\circ} \mathrm{C}$ (fish transferred from 10 to $15^{\circ} \mathrm{C}$ after 34 days of the experiment) (diamonds, no line was fitted) 
Table 1 Fluctuating asymmetry indexes (FA) (Mean \pm SD) of sagittal otolith size calculated for cannibals $(n=71)$ and prey $(n=71)$ of larval pike, Esox lucius, kept under experimental conditions for 45 days

\begin{tabular}{llll}
\hline \multirow{4}{*}{} & \multicolumn{2}{l}{ FA $($ Mean $\pm \mathrm{SD})$} \\
\cline { 2 - 4 } & Otolith area & Otolith length & Otolith width \\
\hline Cannibals & $0.036 \pm 0.002$ & $0.022 \pm 0.002$ & $0.025 \pm 0.002$ \\
Prey & $0.039 \pm 0.002$ & $0.024 \pm 0.002$ & $0.027 \pm 0.002$ \\
\hline
\end{tabular}

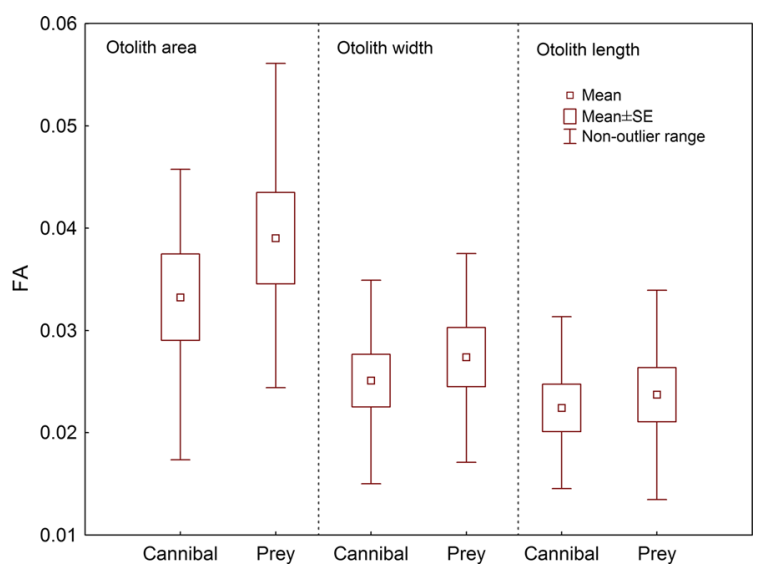

Fig. 8 Comparison (Mean, SD, and non-outlier range) of fluctuating asymmetry (FA) for otolith area, otolith width, and otolith length for larval pike, Esox lucius, cannibals $(n=71)$ and prey $(n=71)$. The differences between cannibals and prey were not statistically significant (t test, $P>0.05$ )

\section{Discussion}

The results of the current study confirmed that cannibalism in pike is a common phenomenon, and it could possibly be a significant factor limiting survival in early developmental stages of the species. However, the cannibalism intensity values obtained in the present research, which were estimated during a few observations daily, were relative only. They were comparable among temperatures, but they did not provide an estimation of the absolute value of total mortality from cannibalism (for example during a $24 \mathrm{~h}$ period). This is especially so because total mortality from cannibalism resulted not only from the consumption of whole larvae, but also from death after bites even if the larvae attacked were not consumed (Szczepkowski, 2009). If we recalculate the mean daily mortality of $0.6 \%$ obtained in the present research during $90 \mathrm{~min} /$ day observations into a $24 \mathrm{~h}$ period, a value of approximately $10 \%$ daily is obtained. This does not include deaths resulting from unsuccessful attacks. However, we believe that such a calculation is too speculative to include it in the results section.

First cannibalistic attack—cannibal size and age

As the results of the present study show, pike cannibalism occurred as early as in the first days of life. The basic pike feeding pattern described by Hunt $\&$ Carbine (1951) can be divided into three stages. The first stage is from the moment pike begin exogenous feeding after yolk-sac resorption until they reach a length of about $25 \mathrm{~mm}$ when they feed mainly on lower crustaceans. In the second stage, which is during the period of growth from 26 to $50 \mathrm{~mm}$ in length, they feed mainly on immature aquatic insects. In the third stage, when pike are longer than $50 \mathrm{~mm}$, the typical diet is composed almost exclusively of fish and other vertebrates. According to encyclopaedic information (Grabowska \& Grabowski, 2013), cannibalism in this typical pattern only appears from a size of approximately $4 \mathrm{~cm}$. Similarly, according to Wright \& Giles (1987), pike larger than $30 \mathrm{~mm}$ feed exclusively on invertebrates. However, it is plausible that the exact timing (i.e. size and age) of the initiation of cannibalism depends on environmental conditions like temperature and feeding conditions.

During our study conducted under experimental conditions, the smallest cannibals observed were $13.0 \mathrm{~mm}\left(22{ }^{\circ} \mathrm{C}\right)$ or $13.4\left(15^{\circ} \mathrm{C}\right)$. However, no cannibalistic attacks occurred at $10{ }^{\circ} \mathrm{C}$. These values are lower than those presented by other researchers to date regarding analyses of material obtained from natural conditions and during experiments. The occurrence of early cannibalistic attacks in the natural environment is confirmed, among others, by Žiliukiene \& Žiliukas (2006), who report for pike that the smallest cannibalistic individuals were only $16 \mathrm{~mm}$ (mean water temperature of $15.7^{\circ} \mathrm{C}$ ). In the analyses conducted by Hunt \& Carbine (1951), the size of the smallest cannibals was $21 \mathrm{~mm}$, while Morrow et al. (1997) report a size of $25 \mathrm{~mm}$. Giles et al. (1986) report that the size of the smallest cannibals under experimental conditions at a temperature of $12{ }^{\circ} \mathrm{C}$ was $30.3 \mathrm{~mm}$. Wright \& Giles (1987) report that cannibalistic attacks among pike cultured in ponds (no 
temperature information was provided) occurred at a size of $49 \mathrm{~mm}$. Kucharczyk et al. (1997) observed attacks committed by smaller sized fish of approximately 18-24 mm during experiments conducted at $20{ }^{\circ} \mathrm{C}$.

In reference to the timing, or larval age, of the occurrence of cannibalism, the first cannibalistic attack at the highest temperature analysed $\left(22{ }^{\circ} \mathrm{C}\right)$ was observed as early as $5 \mathrm{dph}$, while at the temperature of $15{ }^{\circ} \mathrm{C}$, the first attack occurred 10 dph. At the lowest temperature $\left(10^{\circ} \mathrm{C}\right)$ no cannibalistic attacks were noted for 31 days (following which the larvae were transferred to the temperature of $15^{\circ} \mathrm{C}$ ). Kucharczyk et al. (1997) analysed the phenomenon of cannibalism in young pike stages in experimental conditions at a temperature of $20^{\circ} \mathrm{C}$, and the first cannibalistic attacks, similarly to those in the current study at a similar temperature, occurred at 5-7 dph. However, Giles et al. (1986) noted the first cannibalistic fry (at a size of $30.3 \mathrm{~mm}$ ) on $32 \mathrm{dph}$, but since the study was conducted at a lower temperature $\left(12{ }^{\circ} \mathrm{C}\right)$, this could have been a factor limiting the phenomenon of cannibalism in smaller specimens that was similar to that in our study at $10{ }^{\circ} \mathrm{C}$. Other studies report on experiments in which the phenomenon of cannibalism did not occur despite high temperatures (18-24 ${ }^{\circ} \mathrm{C}$ ) (Wolnicki \& Górny, 1997). It is possible that at some point, too high temperature could cause stress that inhibits cannibalistic behaviour, and the results by Wolnicki \& Górny (1997) from $24{ }^{\circ} \mathrm{C}$ could confirm this hypothesis. Our results, however, indicate that if such a stressful level of high temperature exists, it occurs above $22{ }^{\circ} \mathrm{C}$.

The timing (i.e. size and age of larvae or juveniles) of the first cannibalistic attacks depends of course not only on temperature but also on larval density and feeding conditions in tanks or the environment. These differed in the studies cited above. However, even if their results are not fully comparable, they provide some estimation of the timing of the first cannibalistic attack in different conditions, including different temperatures. The early onset of cannibalistic behaviour in our study could have resulted from feeding conditions. Even if the larvae were fed ad libitum, the commercial feed might not have been as efficient as live food (zooplankton, larvae of other fish species) in the natural environment. On the other hand, it could happen frequently that the availability of food in natural conditions is insufficient, and the feeding conditions could be similar to ours or worse. Thus, we assumed that the feeding conditions during the experiment were moderately good and were somewhere between very good and poor feeding conditions in nature.

Another factor affecting when cannibalistic behaviour begins is yolk-sac absorption, which can occur at various times depending on the temperature in which the larval pike are held. Fey et al. (2019) report that yolk-sac resorption in larval pike occurred $6 \mathrm{dph}$ at $12{ }^{\circ} \mathrm{C}$, while Demirci et al. (2017) report it occurring $10 \mathrm{dph}$ at a temperature of $10{ }^{\circ} \mathrm{C}$. In the current study, full yolk-sac resorption occurred $4 \mathrm{dph}$ at a temperature of $22{ }^{\circ} \mathrm{C}, 6 \mathrm{dph}$ at $15{ }^{\circ} \mathrm{C}$, and $9 \mathrm{dph}$ at $10^{\circ} \mathrm{C}$. The timing of yolk-sac resorption corresponded to the appearance of cannibalistic attacks, which were noted from 1 (at $22{ }^{\circ} \mathrm{C}$ ) to $4\left(\right.$ at $15{ }^{\circ} \mathrm{C}$ ) days after absorption. At $10{ }^{\circ} \mathrm{C}$, no cannibalistic attacks were observed for the entire observation period, i.e. 25 days after yolksac resorption.

Thus, it can be concluded that factors facilitating the occurrence of cannibalism among larval pike was yolk-sac resorption and growth to a size of approximately $13 \mathrm{~mm}$. This state can be obtained within 4 to 6 $\mathrm{dph}$, depending on temperatures from 22 to $15^{\circ} \mathrm{C}$, respectively, which indicates a significant positive metabolism effect on the two factors, i.e. time to yolksac absorption and reaching the size of $13 \mathrm{~mm}$. The impact of temperature is not restricted only to limiting the time until yolk-sac absorption and the larvae obtaining a given size. In the present study at a temperature of approximately $10{ }^{\circ} \mathrm{C}$ no attacks were noted even after yolk-sac resorption or when the larvae had achieved sizes considerably larger than $13 \mathrm{~mm}$ (up to $18 \mathrm{~mm}$ ). This indicated that temperature affected the physiological state of the fish (Dabrowski, 1986). Clearly, metabolism and larval activity are reduced significantly and maintained at a minimal level below a certain temperature (Elliot, 1982).

Prey to cannibal size ratio

Nillson \& Bronmark (2000) analysed the behaviour and morphology of pike and concluded that prey size is limited by its body depth and predator gape size. Body depth can be considered as both height and width since pike can attack from a lateral position. In the present work, the ratio of prey to predator ranged, on average, from $95 \%$ for $13 \mathrm{~mm}$ fish to $80 \%$ for $27 \mathrm{~mm}$ 
fish, with a mean for all specimens of $87 \%$. The smallest size difference between predator and prey was just $0.2 \mathrm{~mm}$ and was observed at both $22{ }^{\circ} \mathrm{C}$ and $15{ }^{\circ} \mathrm{C}$. Such a small difference was evident at the beginning of the occurrence of this phenomenon (e.g. $5 \mathrm{dph}$, predator $13 \mathrm{~mm}$ - prey $12.8 \mathrm{~mm}$ ) and during later periods (e.g. $14 \mathrm{dph}$, predator $18.4 \mathrm{~mm}$ - prey $18.2 \mathrm{~mm}$ ). Žiliukienė \& Žiliukas (2006) report that prey length was $90.9 \%$ of pike predators measuring $17.6 \mathrm{~mm}$. However, Hunt \& Carbine (1951) report this proportion was $70 \%$ for pike measuring $23 \mathrm{~mm}$. Bry et al. (1992) demonstrated that for much larger pike held in semi-natural conditions the relative size of the prey in relation to the predator ranged from 35 to $85.4 \%$ and fluctuated linearly from approximately $75 \%$ at a cannibal total length (TL) of $60 \mathrm{~mm}$ to approximately $60 \%$ for cannibals measuring $200 \mathrm{~mm}$ TL. Clearly, the values of the size proportion between prey and predator decreased (larger differences) with predator growth because of increasing differences in size between the smallest and largest larvae in a given tank over time.

Type of cannibalism-direction of the attack

The present results confirm that the first attacks observed for pike within first few weeks after hatching represent type I cannibalism, in which the prey is only partially ingested from the tail or head before it is completely digested. Cannibalism type II, in which prey are completely ingested, appears with increasing size differences between cannibals and prey (Baras \& Jobling, 2002). This type of cannibalism was not observed during the present study.

Cannibalistic attacks among fish during the larval and juvenile periods can target the tail, head, or side of the prey (Baras \& Jobling, 2002). In early developmental stages of fish, including pike, attacks are usually directed at the tail, but as size differentiation increases attacks directed at the head or from the side occur more frequently (Baras, 1999; Baras \& Jobling, 2002; Colchen et al., 2019). Bry et al. (1992) confirm this with observations that $96 \%$ of the prey of pike measuring 60-200 $\mathrm{mm}$ SL were eaten from the head. Attacking larval pike from the head is a fairly common strategy under rearing conditions, and especially at high densities (Kucharczyk et al., 1997). Similar tendencies were observed in the present study when almost all of the attacks observed during the early larval stage occurred from the tail, but as the larvae grew, at a size of approximately $17 \mathrm{~mm}$, attacks from side and the head began to appear and were common if the size difference between cannibal and predator was relatively large.

Temperature effect on cannibalism intensity

Undoubtedly, larval or juvenile density is a decisive factor in the intensity of cannibalism (Giles et al., 1986). Data from the literature on larval pike of a size range of 18-24 mm TL cultured for 12 days at densities of 9,44 , and 88 larvae $\cdot \mathrm{L}^{-1}$ indicated there was increased cannibalism intensity at higher densities (Kucharczyk et al., 1997). In the present study, the inverse relationship was observed; cannibalism intensity increased temporally, which corresponded with decreasing larval density from approximately 34.5 to $0.4 n \cdot \mathrm{L}^{-1}$ (densities at which the cannibals were collected). However, the decrease in density was accompanied by a simultaneous increase in larval length (from approximately $14 \mathrm{~mm}$ to $25 \mathrm{~mm}$ ). Separating these two factors of density and larval size that shifted temporally is impossible, which prevents fully comparing the current results to those obtained by Kucharczyk et al. (1997). Žiliukienè \& Žiliukas (2006) report that the phenomenon of cannibalism in pike measuring from 16-22 $\mathrm{mm}$ occurred at both high (30 larvae $\cdot \mathrm{L}^{-1}$ ) and low (2.3 larvae $\cdot \mathrm{L}^{-1}$ ) densities, but they did not analyse the intensity of this phenomenon. Simultaneously, Žiliukienė \& Žiliukas (2006) confirm that increased cannibalism intensity occurred with larval growth from 16.4 to $28.2 \mathrm{~mm} \mathrm{SL}$, which was also observed in the present study.

Presumably, the observed temperature effect on cannibalism intensity is a consequence of the wellknown phenomenon of the positive impact water temperature has on fish metabolism (e.g. Jobling, 1981). Increased metabolism can, in turn, be responsible for increased feeding intensity (e.g. Johnston \& Mathias, 1994) and also possibly on the intensity of cannibalism. However, since this subject was not studied in the present research, any attempt to explain the possible mechanisms would be too speculative.

Cannibalism and otolith fluctuating asymmetry

FA is considered to be an indicator of developmental instability in organisms (Zakharov, 1992), and as such 
it could impact differences in the stress fish experience and in growth rates. FA is reported to be a useful method to test in various fish species the environmental effects of El Nino conditions (Alados et al.,1993), temperature ( $\mathrm{Lu} \&$ Bernatchez, 1999), pollution (Hardersen, 2000), parasitism (Escós et al., 1995; Loot et al., 2001), salinity (Panfili et al., 2005), and fecundity (Hechter et al., 2000). FA is also useful as an indicator of larval fish condition (Grønkjær \& Sand, 2003; Somarakis et al., 1997b) and stress (Gagliano et al., 2008; Lemberget \& McCornick, 2009; CastilloHidalgo et al., 2018; Landaeta et al., 2018), even if the results obtained by Castillo-Hidalgo et al. (2018) were inconsistent. Most recently, Fey et al. (2020) showed for larval trout the significant effect of a magnetic field of $10 \mathrm{mT}$ on otolith FA of larval trout. The opposite result of larval fish growth rate having no effect on FA is also available (Folkvord et al., 2000; Fey \& Hare, 2008; Kristoffersen \& Magoulas, 2009; Zenteno et al., 2014). Since negative results exist for growth rates and also other indicators (Diaz-Gil, 2015), the usefulness of FA as a fitness and stress indicator is still questioned. In the present study, prey, as opposed to cannibals, represent a group of larvae within a given cohort characterized first of all by slower growth. However, it cannot be excluded that the prey also experience higher stress from being surrounded by larger aggressive individuals. Indeed, for all the otolith size variables the FA index was higher in the present study for prey compared to cannibals, which indicated higher organism instability in the prey. Although these differences were not statistically significant, they can be treated as an indication of the possible effect of differences between cannibals and prey on otolith FA that could be explored in more detail in the future. However, considering the lack of support in the literature for the effect of growth rate differences on FA, the present differences in FA could be related more to the stress experienced than to growth rate differences between cannibals and prey. There is currently no other work that evaluates the FA issue for cannibal/prey groups for comparison.

\section{Conclusions}

Cannibalistic behaviour is a common phenomenon among early life stages of pike, starting as early as 5 dph at a larval size of $13 \mathrm{~mm}$, i.e. as soon as the yolk- sac is absorbed. The phenomenon is affecting individuals with size difference as small as $0.2 \mathrm{~mm}$, which, for larvae from the size range of $13-19 \mathrm{~mm}$, corresponds to approximately $1.3 \%$. The cannibalism could not occur in low temperature and intensify significantly with increased temperatures. No statistically significant differences in otolith FA between cannibals and prey provided no indication of higher organism instability in the prey.

Acknowledgements This paper is a contribution to statutory project Dot17/PIKE conducted at the National Marine Fisheries Research Institute and financed by the Ministry of Science and Higher Education, Poland. We would like to thank Hanna Wróblewska for help with otolith extraction and Adam M. Lejk for consultations on larval rearing.

\section{Compliance with ethical standards}

Conflict of interest statement The authors have no potential conflicts of interest to declare.

Open Access This article is licensed under a Creative Commons Attribution 4.0 International License, which permits use, sharing, adaptation, distribution and reproduction in any medium or format, as long as you give appropriate credit to the original author(s) and the source, provide a link to the Creative Commons licence, and indicate if changes were made. The images or other third party material in this article are included in the article's Creative Commons licence, unless indicated otherwise in a credit line to the material. If material is not included in the article's Creative Commons licence and your intended use is not permitted by statutory regulation or exceeds the permitted use, you will need to obtain permission directly from the copyright holder. To view a copy of this licence, visit http://creativecommons.org/licenses/by/4.0/.

\section{References}

Alados, C. L., J. Escós \& J. M. Emlen, 1993. Developmental instability as an indicator of environmental stress in the Pacific hake (Merluccius productus). Fishery Bulletin NOAA 91: 587-593.

Baras, E., 1999. Sibling cannibalism among juvenile vundu under controlled conditions. I. Cannibalistic behaviour, prey selection and prey size selectivity. Journal of Fish Biology 54: 82-105.

Baras, E. \& M. Jobling, 2002. Dynamics of intracohort cannibalism in cultured fish. Aquaculture Research 33: 461-479.

Bry, C., E. Basset, X. Rognon \& F. Bonamy, 1992. Analysis of sibling cannibalism among pike, Esox lucius, juveniles reared under semi-natural conditions. Environmental Biology of Fishes 35: 75-84.

Campana, S. E., \& Jones, C. M., 1992. Analysis of otolith microstructure data. In Otolith microstructure examination and analysis, pp. 73-100. Ed. by Stevenson D.K., and 
Campana S.E. Canadian Special Publication of Fisheries and Aquatic Sciences. https://doi.org/10.13140/rg.2.2. 22258.61127

Castillo-Hidalgo, G., G. Plaza, M. Díaz-Astudillo \& M. F. Landaeta, 2018. Seasonal variations in the early life traits of Sindoscopus australis (Blennioidei: Dactyloscopidae): hatching patterns, larval growth and bilateral asymmetry of otoliths. Journal of the Marine Biological Association of the United Kingdom 98: 1477-1485.

Clemmesen, C. M., 1988. A RNA and DNA fluorescence technique to evaluate the nutritional condition of individual marine fish larvae. Meeresforschung 32: 134-143.

Colchen, T., P. Fontaine, Y. Ledoré, F. Teletchea \& A. Pasquet, 2019. Intra-cohort cannibalism in early life stages of pikeperch. Aquaculture Research 50: 915-924.

Craig, J. P., \& Kipling. C., 1983. Reproductive effort versus the environment; case histories of Windermere perch, Perca fluviatilis, and pike, Esox lucius. Journal of Fish Biology, 22: 713-27 in J. F. Craig, editor. Pike: biology and exploitation. Chapman and Hall, London. https://doi.org/ 10.1007/978-94-015-8775-4

Craig, J. F. (eds), 1996. Pike: biology and exploitation. Chapman and Hall, London. https://doi.org/10.1007/978-94015-8775-4

Cuff, W., 1980. Behavioral aspects of cannibalism in larval walleye, Stizostedion vitreum. Canadian Journal of Zoology 58: 1504-1507.

Dabrowski, K. R., 1986. Active metabolism in larval and juvenile fish: ontogenetic changes, effect of water temperature and fasting. Fish Physiology and Biochemistry 1: 125-144.

Demirci, S., K. Gokcek, A. Bozkurt, T. Szabo \& B. Urbanyi, 2017. Prey selection and diet composition of larval pike, Esox lucius l., 1758, in lake isaszeg. Hungary. Fresenius Environmental Bulletin 26: 4841-4844.

Diaz-Gil, C., M. Palmer, I. A. Catalán, J. Alós, L. A. Fuiman, E. García, M. del Gil, A. Grau, A. Kang, R. H. Maneja, J. A. Mohan, B. Morro, J. J. Schaffler, L. Buttay, I. RieraBatle, B. Tolosa \& B. Morales-Nin, 2015. Otolith fluctuating asymmetry: a misconception of its biological relevance? ICES Journal of Marine Science 72: 2079-2089.

Dominey, W. J. \& L. S. Blumer, 1984. Cannibalism of early life stages in fishes. In Hrdy, S. B. \& G. Hausfater (eds), Infanticide. Comparative and Evolutionary Perspectives. Aldine, New York: 43-64.

Elliot, J. M., 1982. The effects of temperature and ration size on the growth and energetics of salmonids in captivity. Comparative Biochemistry and Physiology 73B: 81-91.

Escós, J., C. L. Alados, J. M. Emlen \& S. Alderstein, 1995. Development instability in the hake parasitized by Myxosporeans Kudoa spp. Transactions of the American Fisheries Society 124: 943-945.

Fey, D. P., 2018. The effect of preserving ichthyoplankton samples in alcohol on the accuracy of data obtained from otolith microstructure examinations. Fisheries Research 206: 198-201.

Fey, D. P. \& J. A. Hare, 2008. Fluctuating asymmetry in the otoliths of a larval Atlantic menhaden (Brevoortia tyrannus) - a condition indicator? Journal of Fish Biology 72: 121-130.
Fey, D. P., A. M. Lejk \& M. Greszkiewicz, 2018. Daily deposition of growth increments in sagittae and lapilli of laboratory-reared larval northern pike (Esox lucius). Fisheries Bulletin NOAA 116: 302-309.

Fey, D. P., M. Greszkiewicz, Z. Otremba \& E. Andrulewicz, 2019. Effect of static magnetic field on the hatching success, growth, mortality, and yolk-sac absorption of larval Northern pike Esox lucius. Science of the Total Environment 647: 1239-1244.

Fey, D. P., M. Greszkiewicz, A. M. Lejk, M. Jakubowska, Z. Otremba, E. Andrulewicz \& B. Urban-Malinga, 2020. Otolith fluctuating asymmetry in larval trout, Oncorhynchus mykiss Walbaum, as an indication of organism bilateral instability affected by static and alternating magnetic fields. Science of the Total Environment 707: 135489.

Folkvord, A., 1997. Ontogeny of cannibalism in larval and juvenile fishes with special emphasis on Atlantic cod. Chapman and Hall Fish and Fisheries Series 21: 251-278.

Folkvord, A., L. Ystanes, A. Johannessen \& E. Moksness, 1996. RNA:DNA ratios and growth of herring (Clupea harengus) larvae reared in mesocosms. Marine Biology 126: 591-602.

Folkvord, A., G. Blom, A. Johannessen \& E. Moksness, 2000. Growth-dependent age estimation in herring (Clupea harengus) larvae. Fisheries Research 46: 91-103.

Fox, L. R., 1975. Cannibalism in natural populations. Annual Review of Ecology and Systematics 6: 87-106.

Gagliano, M., M. Depczynski, S. D. Simpson \& J. Moore, 2008. Dispersal without errors: symmetrical ears tune into the right frequency for survival. Proceedings of the Royal Society B: Biological Sciences 275: 527-534.

Garcia, V. J. A. \& E. Zaniboni-Filho, 2006. El Canibalismo en la Larvicultura de Peces. Rev MVZ Cordoba 11: 9-19.

Giles, N., R. M. Wright \& M. E. Nord, 1986. Cannibalism in pike fry, Esox lucius L.: some experiments with fry densities. Journal of Fish Biology 29: 107-113.

Grabowska, J. \& M. Grabowski, 2013. Ilustrowana encyclopedia ryb Polski. Dom Wydawniczy PWN Sp. Z o.o, Warszawa. [in Polish.].

Greszkiewicz, M. \& D. P. Fey, 2018. Effect of Preservation in Formalin and Alcohol on the Growth Rate Estimates of Larval Northern Pike. North American Journal of Fisheries Management 38: 601-605.

Grønkjær, P. \& M. K. Sand, 2003. Fluctuating asymmetry and nutritional condition of Baltic cod (Gadus morhua) larvae. Marine Biology 143: 191-197.

Håkanson, J. L., 1989. Condition of larval anchovy (Engraulis mordax) in the Southern California Bight, as measured through lipid analysis. Marine Biology 102: 153-159.

Hardersen, S., 2000. The role of behavioural ecology of damselflies in the use of fluctuating asymmetry as a bioindicator of water pollution. Ecological Entomology 25: 45-53.

Hechter, R. P., P. F. Moodie \& G. E. E. Moodie, 2000. Pectoral fin asymmetry, dimorphism and fecundity in the brook stickleback, Culea inconstans. Behavior 137: 999-1009.

Hunt, B. P. \& W. F. Carbine, 1951. Food of Young Pike, Esox Lucius L., and Associated Fishes in Peterson's Ditches, Houghton Lake, Michigan. Transactions of the American Fisheries Society 80: 67-83. 
Jin, S., X. Yan, H. Zhang \& W. Fan, 2015. Weight-length relationships and Fulton's condition factors of skipjack tuna (Katsuwonus pelamis) in the western and central Pacific Ocean. PeerJ 3: e758.

Jobling, M., 1981. The influences of feeding on the metabolic rate of fishes: a short review. Journal of Fish Biology 18: 385-400.

Johnston, T. A. \& J. A. Mathias, 1994. The effects of temperature on feeding in zooplanktivorous walleye, Stizostedion vitreum, larvae. Environmental Biology of Fishes 40: 189-198.

Kristoffersen, J. B. \& A. Magoulas, 2009. Fluctuating asymmetry and fitness correlations in two Engraulis encrasicolus populations. Journal of Fish Biology 75: 2723-2736.

Kucharczyk, D., A. Mamcarz, R. Kujawa \& A. Skrzypczak, 1997. Development of cannibalism in larval northern pike, Esox lucius (Esocidae). Italian Journal of Zoology 65: 261-263.

Landaeta, M. F., G. Castillo-Hidalgo \& C. Bustos, 2018. Effects of salinity gradients on larval growth and otolith asymmetry of austral hake Merluccius australis. Latin American Journal of Aquatic Research 46: 212-218.

Larsson, P., P. Tibblin, P. Koch-Schmidt, O. Engstedt, J. Nilsson, O. Nordahl \& A. Forsman, 2015. Ecology, evolution and management strategies of Northern pike populations in the Baltic Sea. AMBIO A Journal of the Human Environment 44: 451-461.

Lehtonen, H., E. Leskinen, R. Selen \& M. Reinikainen, 2009. Potential reasons for the changes in the abundance of pike, Esox lucius, in the western Gulf of Finland, 1939-2007. AMBIO A Journal of the Human Environment 16: 484-491.

Lemberget, T. \& M. McCormick, 2009. Replenishment success linked to fluctuating asymmetry in larval fish. Oceanologia 159: 83-93.

Loot, G., S. Lek, S. P. Brown \& J. F. Guegan, 2001. Phenotypic modification of roach (Rutilus rutilus L.) infected with Ligula intestinali L. (Cestoda: Pseudophyllidea). Journal of Parasitology 87: 1002-1010.

Lu, G. Q. \& L. Bernatchez, 1999. A study of fluctuating asymmetry in hybrids of dwarf and normal lake whitefish ecotypes (Coregonus clupeaformis) from different glacial races. Heredity 83: 742-747.

Mamcarz, A., D. Kucharczyk, R. Kujawa, A. Skrzypczak \& G. Furgala-Selezniow, 1998. Ontogeny of feeding habits in northern pike, Esox lucius (Esocidae), larvae reared in illuminated cages. Italian Journal of Zoology 65: 251-253.

McCormick, M. I. \& B. W. Molony, 1993. Quality of the reef fish Upeneus tragula (Mullidae) at settlement: is size a good indicator of condition? Marine Ecology Progress Series 98: 45-54.

Morrow Jr., J. V., G. L. Miller \& K. J. Killgore, 1997. Density, size, and foods of larval northern pike in natural and artificial wetlands. North American Journal of Fisheries Management 17: 210-214.

Naumowicz, K., J. Pajdak, E. Terech-Majewska \& J. Szarek, 2017. Intracohort cannibalism and methods for its mitigation in cultured freshwater fish. Reviews in Fish Biology and Fisheries 27: 193-208.

Nelson, J. S., 1984. Fishes of the World. Wiley, New York: 416.
Nilsson, J., O. Engstedt \& P. Larsson, 2014. Wetlands for northern pike (Esox lucius L.) recruitment in the Baltic Sea. Hydrobiologia 721: 145-154.

Palmer, A. R., 1994. Fluctuating asymmetry analysis: a primer. In Markow, T. A. (ed.), Developmental Instability: Its Origins and Evolutionary Implications. Kluwer, Dordrecht: 335-364.

Panfili, J., J.-D. Durand, K. Diop, B. Gourène \& M. Simier, 2005. Fluctuating asymmetry in fish otoliths and heterozygosity in stressful estuarine environments (West Africa). Marine and Freshwater Research 56: 505-516.

Peck, M. A., H. Baumann, C. Clemmesen, J.-P. Herrmann, M. Moyano \& A. Temming, 2015. Calibrating and comparing somatic-, nucleic acid-, and otolith-based indicators of growth and condition in young juvenile European sprat (Sprattus sprattus). Journal of Experimental Marine Biology and Ecology 471: 217-225.

Pereira, L. S., A. A. Agostinho \& K. O. Winemiller, 2017. Revisiting cannibalism in fishes. Reviews in Fish Biology and Fisheries 27: 499-513.

Polis, G. A., 1981. The evolution and dynamics of intraspecific predation. Annual Review of Ecology, Evolution, and Systematics 12: 225-251.

Skov, C., \& Nilsson, P. A. (eds), 2018. Biology and ecology of pike. CRC Press, Taylor \& Francis Group, Boca Raton.

Smith, C. \& P. Reay, 1991. Cannibalism in teleost fish. Reviews in Fish Biology and Fisheries 1: 41-64.

Somarakis, S., I. Kostikas \& N. Tsimenides, 1997a. Fluctuating asymmetry in the otoliths of larval fish as an indicator of condition: conceptual and methodological aspects. Journal of Fish Biology 51: 30-38.

Somarakis, S., I. Kostikas, N. Peristeraki \& N. Tsimenides, 1997b. Fluctuating asymmetry in the otoliths of larval anchovy Engraulis encrasicolus and the use of developmental instability as an indicator of condition in larval fish. Marine Ecology Progress Series 151: 191-203.

Sullivan, K., D. C. Smith \& A. Gason, 1993. Getting the right information for age-structured models. In Hancock, D. A. (ed.), Population Dynamics for Fisheries Management. Australian Society For Fish Biology, Perth: 91-98.

Szczepkowski, M., 2009. Impact of selected abiotic and biotic factors on the results of rearing juvenile stages of northern pike Esox lucius $L$. in recirculating systems. Archives of Polish Fisheries 17: 107-147.

Szczepkowki, M., Z. Zakęś, A. Kapusta, B. Szczepkowska, M. Hopko, S. Jarmołowicz, A. Kowalska, M. Kozłowski, K. Partyka, I. Piotrowska \& K. Wunderlich, 2012. Growth and survival in earthen ponds of different sizes of juvenile pike reared in recirculating aquaculture systems. Archives of Polish Fisheries 20: 267-274.

Szczerbowski, A., 2008. Rybactwo Śródlądowe [in Polish]. IRS Olsztyn, ss. 608.

Theilacker, G. H., 1986. Starvation-induced mortality of young sea-caught jack-mackerel, Trachurus symmetricus, determined with histological and morphological methods. Fishery Bulletin NOAA 84: 1-17.

Wolnicki, J. \& W. Górny, 1997. Effects of commercial dry diets and water temperature on growth and survival on northern pike, Esox lucius L., larvae. Polish Archives Of Hydrobiology 44: 377-383. 
Wright, R. M. \& N. Giles, 1987. The survival, growth and diet of pike fry, Esox lucius L., stocked at different densities in experimental ponds. Journal of Fish Biology 30: 617-629.

Zakharov, V. M., 1992. Population phenogenetics: analysis of developmental stability in natural populations. Acta Zoologica Fennica 191: 7-30.

Zenteno, J. I., C. A. Bustos \& M. F. Landaeta, 2014. Larval growth, condition and fluctuating asymmetry in the otoliths of a mesopelagic fish in an area influenced by a large Patagonian glacier. Marine Biology Research 10: 504-514.
Žiliukienè, V. \& V. Žiliukas, 2006. Feeding of early larval pike Esox lucius L. reared in illuminated cages. Aquaculture 258: 378-387.

Publisher's Note Springer Nature remains neutral with regard to jurisdictional claims in published maps and institutional affiliations. 